\title{
Low-Cost UAV for High-Resolution and Large-Scale Coastal Dune Change Monitoring Using Photogrammetry
}

\author{
Quentin Laporte-Fauret ${ }^{1, *}$, Vincent Marieu ${ }^{1}$ (), Bruno Castelle ${ }^{1}$, Richard Michalet ${ }^{1}$, \\ Stéphane Bujan ${ }^{1}$ and David Rosebery ${ }^{2}$ \\ 1 CNRS, Université de Bordeaux, UMR 5805 EPOC, 33615 Pessac CEDEX, France; \\ vincent.marieu@u-bordeaux.fr (V.M.); bruno.castelle@u-bordeaux.fr (B.C.); \\ richard.michalet@u-bordeaux.fr (R.M.); stephane.bujan@u-bordeaux.fr (S.B.) \\ 2 Office National des Forêts, 75570 CEDEX 12 Paris, France; david.rosebery@onf.fr \\ * Correspondence: quentin.laporte-fauret@u-bordeaux.fr; Tel.: +33-540-003-316
}

Received: 31 January 2019; Accepted: 1 March 2019; Published: 7 March 2019

\begin{abstract}
In this paper, coastal dune data are collected at Truc Vert, SW France, using photogrammetry via Unmanned Aerial Vehicles (UAVs). A low-cost GoPro-equipped DJI Phantom 2 quadcopter and a 20 MPix camera-equipped DJI Phantom 4 Pro quadcopter UAVs were used to remotely sense the coastal dune morphology over large spatial scales ( $4 \mathrm{~km}$ alongshore, i.e., approximately $1 \mathrm{~km}^{2}$ of beach-dune system), within a short time (less than $2 \mathrm{~h}$ of flight). The primary objective of this paper is to propose a low-cost and replicable approach which, combined with simple and efficient permanent Ground Control Point (GCP) set-up, can be applied to routinely survey upper beach and coastal dune morphological changes at high frequency (after each storm) and high resolution $(0.1 \mathrm{~m})$. Results show that a high-resolution and accurate Digital Surface Model (DSM) can be inferred with both UAVs if enough permanent GCPs are implemented. The more recent DJI Phantom 4 gives substantially more accurate DSM with a root-mean-square vertical error and bias of $0.05 \mathrm{~m}$ and $-0.03 \mathrm{~m}$, respectively, while the DSM inferred from the DJI Phantom 2 still largely meets the standard for coastal monitoring. The automatic flight plan procedure allows replicable surveys to address large-scale morphological evolution at high temporal resolution (e.g., weeks, months), providing unprecedented insight into the coastal dune evolution driven by marine and aeolian processes. The detailed morphological evolution of a 4-km section of beach-dune system is analyzed over a 6-month winter period, showing highly alongshore variable beach and incipient foredune wave-driven erosion, together with wind-driven inland migration of the established foredune by a few meters, and alongshore-variable sand deposition on the grey dune. In a context of widespread erosion, this photogrammetry approach via low-cost flexible and lightweight UAVs is well adapted for coastal research groups and coastal dune management stakeholders, including in developing countries where data are lacking.
\end{abstract}

Keywords: digital surface model; unmanned aerial vehicle; photogrammetry; coastal dune; aeolian erosion; marine erosion; low-cost survey

\section{Introduction}

Photogrammetry using Unmanned Aerial Vehicles (UAVs) has been increasingly used in recent years to remotely sense topographic data in different fields of geoscience like gully erosion [1], beach dune system evolution [2-6], tidal inlet evolution [7], rocky cliff erosion [8], volcanic gas measurements [9] and eroding sub-humid badlands [10]. Photogrammetry allows for reconstructing a 
3D structure using overlapping offset images with photogrammetry software (e.g., Agisoft Metashape, Pix4D), which are able to take a set of images and calculate the positions and orientations of the cameras using an iterative bundle adjustment procedure to generate a cloud of points in 3D. However, the generated point cloud needs be aligned with a coordinate system. Generally, this step is performed using ground control points (GCPs), the coordinates for which are obtained from ground surveys (e.g., using a DGPS). These GCPs must be clearly visible on the images to further assign a corresponding coordinate [11].

Coastal areas show complex morphological changes over a wide range of temporal and spatial scales [12]. Monitoring the evolution of coastal systems can be carried out using several methods. For instance, reference [13] used photogrammetry with Pleiades satellite images to obtain DTMs in mountainous areas, with, after optimization, horizontal and vertical accuracy of $0.5 \mathrm{~m}$ and $1.0 \mathrm{~m}$, respectively, but the spatial and temporal resolution remain much larger than those possible with UAVs. High resolution DSM can also be obtained by a terrestrial or airborne LiDAR. These optical remote sensing techniques use the flight time of laser pulses reflected by the surface of the points. The objects reflecting the laser beam are referenced using the position of the acquisition sensor, allowing us to acquire millions of points, before being corrected and referenced in an international system, in order to generate DTMs. These methods are used extensively for monitoring coastal areas [14-19] and can reach a spatial resolution of about $0.1 \mathrm{~m}$. The airborne LiDAR allows for monitoring a very large-scale area with high precision and resolution, and also vegetation penetration, but the high cost and the long processing time of each survey is prohibitive for monitoring the coast at high frequency (i.e., monthly, seasonally). On the other hand, the terrestrial LiDAR is cheaper, but it is time consuming to implement, provides limited spatial coverage and is intrusive. It is therefore not well adapted to survey fragile ecosystems over large areas. More recently photogrammetry was introduced, using different platforms such as microlight aircraft flying high over large-areas $[4,20]$, wind-sensitive and unstable kites [21] and more commonly UAVs [22]. Contrary to most of these studies [1-10], our contribution (1) uses high-resolution fish eye lens and regular-angle lens; (2) is based on a permanent GCPs spatial distribution with automatized flight plan and waypoints software for high replicability and (3) covers a large area.

Along coastlines with ample supply of sand, prevailing onshore winds, and presence of vegetation or other obstructions trapping the windblown sand, coastal dunes have developed worldwide when not destroyed by humans [23]. After the onset of sediment deficit in most coastal areas in the mid-20th century, many observations highlighted that coastal dunes buffer storm waves and greatly enhance beach resilience (e.g., reference [24]). In the context of Climate Change (sea level rise, increase in storminess) and increasing anthropogenic pressure, dunes are therefore more than ever a critical component to the future of our coasts $[25,26]$. Vegetated coastal dunes also host leisure activities and provide outstanding ecosystem values and services such as nest or incubation sites, filtering of pollutants and ecological niches for plants that are adapted to dynamic conditions [27]. Insightful large-scale coastal dune studies have mostly focused on geomorphological and vegetation aspects in qualitative ways (e.g., reference [28]). Otherwise, more quantitative coastal dune studies have focused on limited areas to address only one of the coastal dune components, e.g., foredune initiation and formation (e.g., reference [22]) and short-term storm-driven marine erosion [29]. The dynamics of the composite beach-dune system are poorly understood, notably because of the lack of high-resolution, large-scale, morphological data across the entire beach-dune system. Overall, although marine erosion can drive large elevation changes of the beach-dune system (e.g., $>2 \mathrm{~m}$ across the beach and $>5 \mathrm{~m}$ at the foredune in reference [29]), severe windstorms can drive more subtle vertical changes (a few tens of centimeters) across the entire coastal dune (e.g., reference [30]) which are critical to the overall sediment budget. Therefore, accurate beach-dune monitoring programs must typically provide morphological data with vertical errors smaller than, say, $0.1 \mathrm{~m}$.

Because coastal dunes are fragile systems, using non-intrusive remote sensing techniques to monitor morphological changes is a necessary requirement. In addition, coastal dunes typically cover 
large spatial scales, i.e., on the order of kilometers and hundreds of meters in the alongshore and cross-shore directions, respectively, with morphological changes occurring on the timescales from hours (storms) to seasons and years. Accurate ( $<0.1 \mathrm{~m}$ vertical errors) high spatial resolution $(<0.5 \mathrm{~m})$ is also required to accurately monitor the evolution of, for instance, the dune scarp and incipient blowouts and more vertically subtle but larger scale patterns. Therefore, photogrammetry using UAVs appears as the ideal candidate to monitor beach-dune morphological changes at these temporal and spatial scales. Although this approach is already used to monitor rock cliff erosion [8] or beach morphodynamics [2-6], it has been rarely applied to coastal dunes so far. A notable exception is the study by reference [2] on a beach-dune system in Italy. Although the approach was found to be efficient with a vertical accuracy comparable to that of the terrestrial LiDAR technology, the study was performed on a reasonably small zone (around $0.015 \mathrm{~km}^{2}$ ). This coverage is too small to address the overall beach-dune morphological changes. For instance, even along straight open coasts, beach-dune morphological storm-driven erosion patterns can have alongshore scales of up to $1 \mathrm{~km}$ owing to the formation of megacusp embayments [29,31], and the onset of blowouts and post-storm foredune recovery can also be strongly non-uniform alongshore at these scales (e.g., reference [32]). Another notable exception is the recent pioneering study of reference [33] who twice a year surveyed morphological changes along $800 \mathrm{~m}$ of coastal dune. However, the survey strategy was not replicable as the number of GCPs, images and the flight plan varied from one survey to another. It is noteworthy that another reason why coastal dunes have never been intensively surveyed through UAV photogrammetry on large scales (say $>1 \mathrm{~km}$ ) is UAV legislation restricting the distance between the UAV and the pilot in many countries.

In this paper, we develop a low-cost, lightweight and replicable UAV photogrammetry protocol with two different UAVs, one equipped with a fisheye lens camera and the second, more recent, equipped with a high-resolution camera providing weakly-distorted high-resolution images. The primary objective is to show that, using the simple and efficient GCP set-up developed herein, the protocol can be applied to routinely survey upper beach and coastal dune large-scale morphological changes at high resolution. The second objective is to determine whether a very low-cost UAV equipped with a fisheye-lens action camera can monitor the morphological evolution of beach-dune systems with an accuracy meeting coastal monitoring requirements, or if latest generation off-the-shelf camera-equipped UAVs are necessary. This approach is further used to address the beach-dune morphological changes in SW France driven by the combination of marine and aeolian processes during the winter of $2017 / 2018$. We show that this approach can provide unprecedented insight into beach-dune dynamics across the entire system under the combined action of storm wind and waves. In addition, this protocol can also be used to assess the influence of coastal dune management on dune geomorphology, coastal change and biodiversity.

\section{Field Site}

The study site is Truc Vert beach, SW France, which is representative of most of the open sandy beaches of the 110-km long Gironde coast (Figure 1). Some small coastal towns, with limited coastal defenses, are present along this coast. The Gironde coast is made of meso-macrotidal beaches with mean annual and maximal spring tide ranges of $3.7 \mathrm{~m}$ and $5 \mathrm{~m}$, respectively [29]. Gironde beaches, backed by high and wide coastal dunes, are exposed to both wave and wind actions. The wave climate is characterized by a dominant WNW direction, generated in the North Atlantic Ocean, with a mean significant wave height $H s=1.7 \mathrm{~m}$, and a mean peak period $T p=10.3 \mathrm{~s}$. Winter wave activity is strongly interannually variable [34] and has been increasingly energetic over the last decades owing to large-scale atmospheric pattern variability in the North Atlantic ocean [35]. The prevalent winds have a WNW direction and a mean velocity of $0.4 \mathrm{~m} / \mathrm{s}$ and $0.7 \mathrm{~m} / \mathrm{s}$ during summer and winter, respectively. Chronic erosion rates vary from 0 near Truc Vert to locally $5.0 \mathrm{~m} /$ year in the north where the depleted coastal dune system leaves the coastal forest exposed to marine erosion [33]. While chronic erosion is observed throughout the years essentially at the most northern sites, series of severe winter storms can also cause coastal erosion along the entire Gironde coast. A recent striking example is the winter of 
2013/2014 which caused widespread dune erosion $[29,36]$. Figure $1 \mathrm{~b}$ shows the different morphological compartments of the beach-dune system at Truc Vert beach, namely: the beach, a wave deposited accumulation of sand [37]; the incipient foredune, a developing foredune formed by aeolian sand deposition with the presence of pioneer plant communities; the foredune, a shore-parallel dune ridge formed on the backshore by aeolian sand deposition and vegetation mostly composed of marram grass; and the grey dune, also called the established foredune, occupying the most inland position at the rear of the beach and is characterized by intermediate or woody plant species [38].
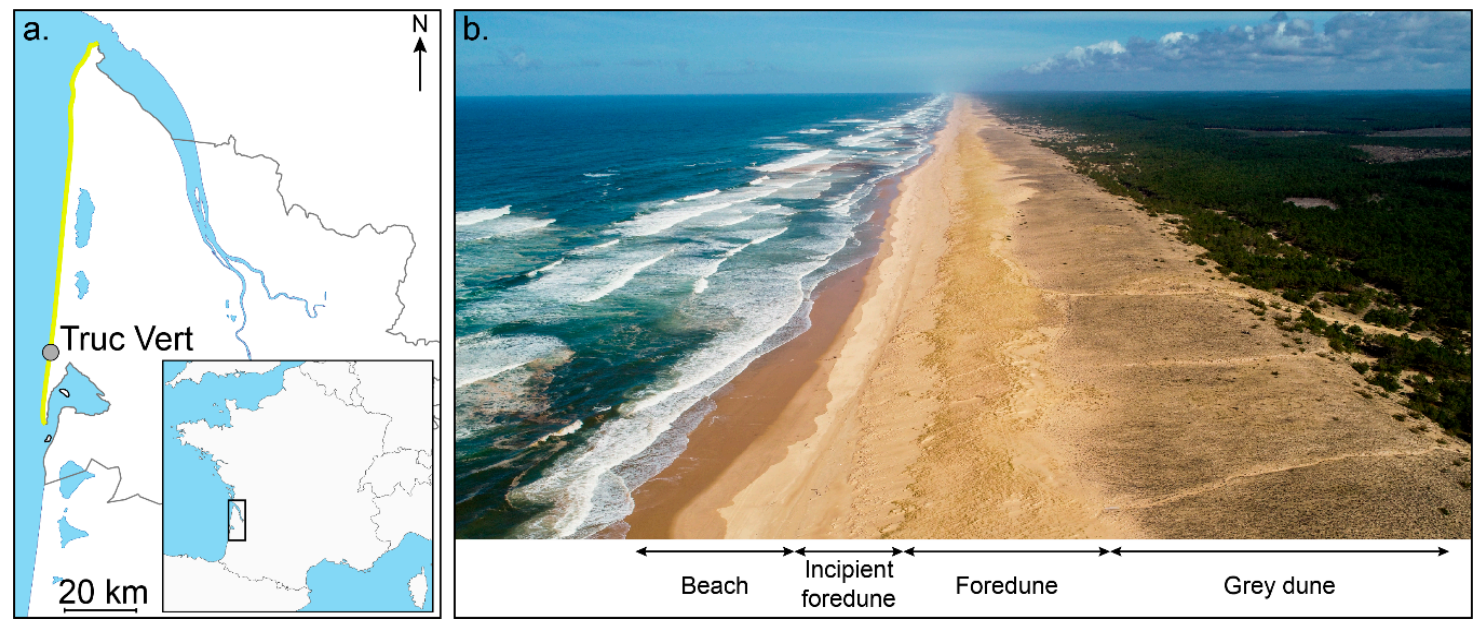

Figure 1. (a) Map of the Gironde coast (yellow line) in SW France with location of Truc Vert beach, (b) Truc Vert beach with a well-managed alongshore-uniform coastal dune (Ph. V. Marieu).

The coastal dune system of the Gironde coast was first established in the nineteenth century but subsequently suffered severe damage from some major winter storms in the 1910s and 1920s and from the Second World War. During the latter period, the coastal dunes were restricted areas used as a source of aggregate to build the Nazi blockhouses. Until the early 1960s the coastal dunes were in serious disrepair as they were being eroded by the sea and dissected by blowouts [39]. The coastal dune managers of the French National Forest Office (ONF) undertook extensive renovation between the 1960s and the 1980s, involving extensive dune profiling and marram planting. Since then, the ONF has been managing the dune through, for instance, fencing to inhibit the development of blowouts or planting to help beach-dune recovery through foredune growth that is maintaining the coastal dune as a fixed and reasonably alongshore-uniform feature [40].

\section{Materials and Methods}

\subsection{Low-Cost UAV, Camera and Permanent GCP Implementation}

The system is composed of an UAV with its remote controller, a video return system, a standard PC or a tablet with a mission planning software or application (Figure 2a), and permanent GCPs implemented on the coastal dune (Figure 2b). Two low-cost UAVs are used from which the remotely-sensed DSMs will be further compared. The first is a DJI Phantom 2 (DP2) quadcopter, slightly modified to respect the French legislation allowing to fly a drone within $1 \mathrm{~km}$ horizontally from the pilot. The UAV is equipped with a GoPro Hero 4 Black edition, mounted on a DJI Zenmuse H3-3D brushless gimbal that ensures a three-axis camera stabilization. The total weight of the UAV is $1.7 \mathrm{~kg}$ with a flight autonomy between $20 \mathrm{~min}$ and $25 \mathrm{~min}$ in mild weather conditions. The GoPro camera takes 12 MPix images with a very wide horizontal field of view of $122.6^{\circ}$, allowing large spatial coverage for low altitude flights, but with severe barrel distortion typical of fisheye lenses. The widest available field of view was chosen in order to minimize both the number of flights necessary to cover the entire zone and computation time. The second UAV is a standard DJI Phantom 4 Pro (DP4P) 
quadcopter. The weight of this UAV is $1.4 \mathrm{~kg}$ with a flight autonomy up to $30 \mathrm{~min}$ in mild weather conditions. The DP4P quadcopter is equipped with a 20 MPix camera, with a horizontal field of view of $74^{\circ}$, mounted on a Phantom 4 Pro Gimbal. Contrary to the GoPro-equipped DP2 quadcopter, the images taken by DP4P are much less distorted, but provide a smaller field of view. Primarily for replicability purposes, all the missions except the landings are fully automated using Ground Station software on a standard PC for DP2, and Litchi application (from VC technology Ltd, Brooksville, FL, USA) on an Android tablet for DP4P. During the flight, the drone position, the battery and status, and the captured images are continuously monitored on the remote screen.
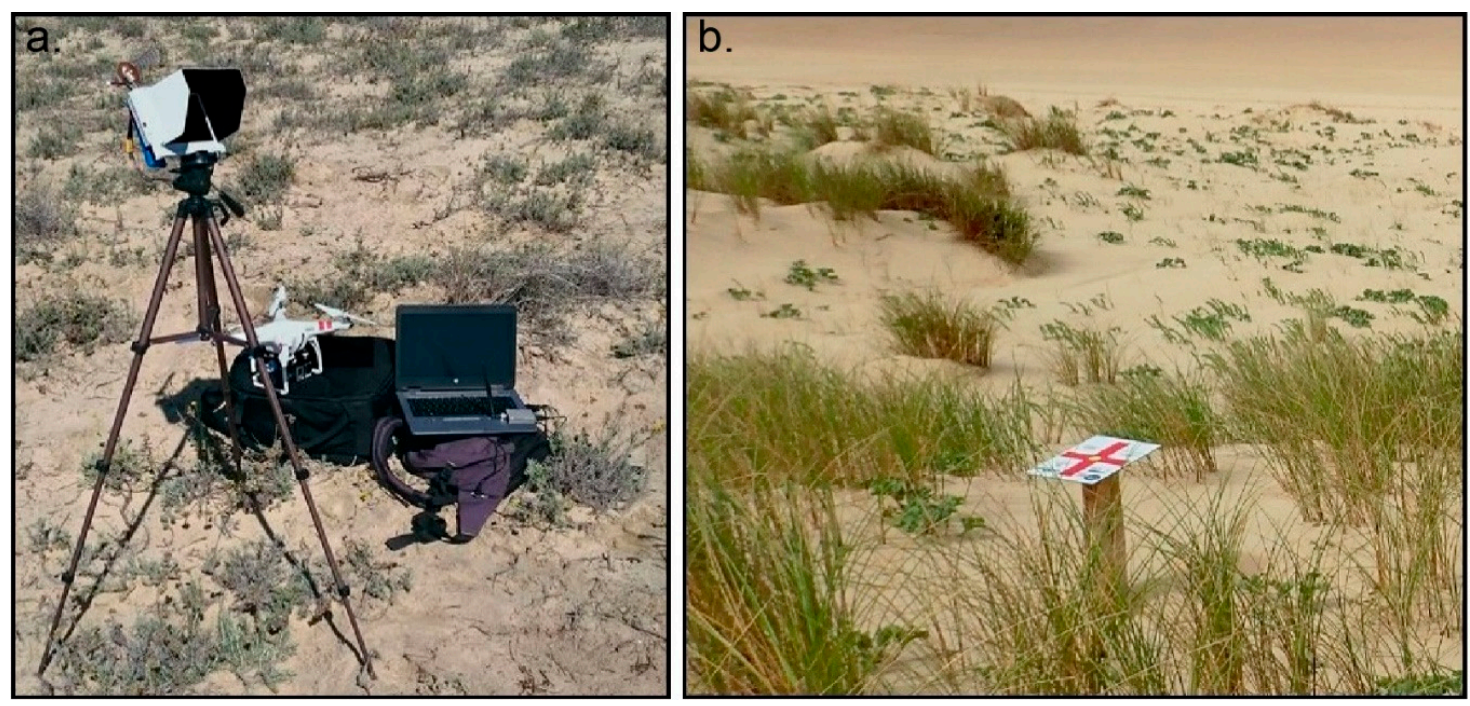

Figure 2. The dune survey system composed of (a) light and low-cost UAV hardware, computer ground station, video receiver, and (b) permanent GCPs spaced every $250 \mathrm{~m}$ and approximately 50-100 $\mathrm{m}$ in the alongshore and cross-shore directions, respectively.

Truc Vert beach is monitored along a 4-km stretch of beach-dune system. Given the limited flight range from the operator $(<1 \mathrm{~km})$, the full $4-\mathrm{km}$ survey with DP2 requires two take-off/landing points, with two flights from each point, for a total of 4 flights of 15 min each with $80 \%$ image overlapping in the flight direction and a minimum of $50 \%$ in the normal direction. Due to the very wide camera angle, only four alongshore paths are needed to photograph the entire width of the system from the beach to the grey dune (see Figure 3 for a zoom onto a 1-km long stretch of the beach-dune system). The UAV is set to fly at approximately $6.5 \mathrm{~m} / \mathrm{s}$ and $65 \mathrm{~m}$ high, which is roughly $40 \mathrm{~m}$ and $60 \mathrm{~m}$ above the dune crest and the upper beach respectively, allowing us to obtain a mean Ground Sampling Distance (GSD) of $4.5 \mathrm{~cm} /$ pix. Indeed, because of the fish eye lens, the GSD ranges from $2.5 \mathrm{~cm} /$ pix in the center of the image to $8.8 \mathrm{~cm} /$ pix at the edges. In contrast, the smaller field of view of the DP4P camera requires 8 paths to photograph the entire width of the beach-dune system (Figure 3). The entire survey is performed with 4 flights of 20 min each from 4 different take-off/landing points, with $75 \%$ image overlapping in the flight direction and a minimum of $55 \%$ in the normal direction. The UAV is set to fly at approximately $8 \mathrm{~m} / \mathrm{s}$ and $85 \mathrm{~m}$ high, which is roughly $60 \mathrm{~m}$ and $80 \mathrm{~m}$ above the dune crest and the upper beach, respectively, allowing to obtain a mean GSD of $1.78 \mathrm{~cm} /$ pix. The autonomy of the DP4P and the quality of the camera results in a better GSD with the same number of flights. For both UAVs, the cameras are programmed to take one image every $2 \mathrm{~s}$. 


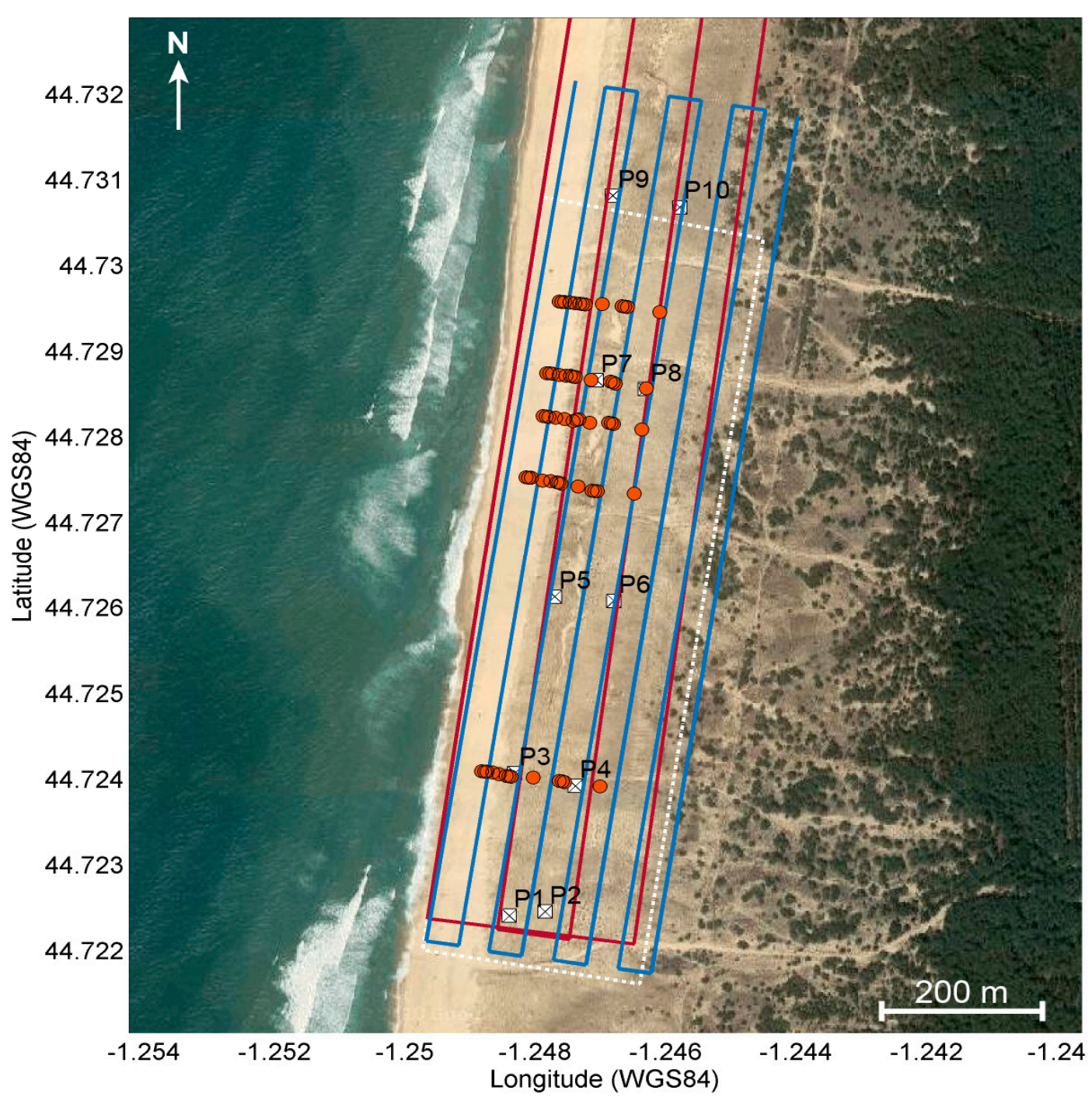

Figure 3. Zoom onto the 1-km southern end of the 4-km field size. This 1-km section corresponds to the location of the validation experiment delimited by the dotted white box. P1-P10 indicate the location of the permanent GCPs, the alongshore red lines and blue lines represent DP2 and DP4P flight trajectories, respectively, and the orange dots show the DGPS survey points used for the validation experiment.

An array of 36 permanent GCPs were implemented two by two every $250 \mathrm{~m}$ alongshore on the coastal dune of Truc Vert (Figure 2b). They are composed of an A4-format aluminum composite target (weather resistant with high rigidity and flatness) fixed onto a large wooden post buried approximately 1-m deep in the sand to ensure GCP stability and horizontality. The target consisted of a red cross and a yellow circle in the center of the target. GCPs are checked once or twice a year using a Trimble Differential GPS with a known base, allowing us to obtain a vertical and horizontal accuracy of $0.015 \mathrm{~m}$ and $0.008 \mathrm{~m}$, respectively. A study conducted by reference [41] showed that an edge or stratified GCP distribution over a given study area results in increased horizontal and vertical accuracy. However, the central distribution used at Truc Vert was motivated by the impossibility to implement permanent GCPs on the beach owing to vertical beach changes easily on the order of meter during winter storms [26,31] and during subsequent longer recovery periods [28,42]. Therefore GCPs were placed in the less mobile areas of the coastal dune, i.e., at the back of the foredune and within the grey dune (Figure $2 b$ ). 


\subsection{Photogrammetry}

There are several commercial (Agisoft Metashape, Pix4D) or free (MicMac, Visual SFM) forms of photogrammetry software. Herein, data processing was carried out using Structure-from-Motion (SfM) algorithm through Agisoft Photoscan Pro software v1.2.6 (Agisoft Photoscan software has now become Agisoft Metashape), which is used by many research groups worldwide and does not require a very high level of expertise in stereo-photogrammetry. Despite the algorithms used to process the images not being public, the different steps of the process are configurable and can be fairly controlled. Photoscan shows good skill to reconstruct landscape 3D point clouds [22,43]. It is able to deal with the strong distortion of fisheye cameras [44], and it has been successfully used to process UAV images in coastal environments $[7,16,22,45]$. The procedure to obtain a DSM from UAV-taken images is as follows: (1) the images from each survey are uploaded in the software, the camera type is chosen, "fisheye" for DP2, which corrects the distortion of the GoPro images (distortion correction using "frame" camera type yields less accurate DEM, not shown here), and "frame" for DP4P, and camera alignment is performed through SfM algorithm to obtain a sparse 3D point cloud; (2) the GCP positions are selected manually on the images with an accuracy smaller than 0.5 pixel and, given that lens characteristics are substantially affected by temperature and insolation variations with surveys performed throughout the year with outside temperatures ranging approximately $0-35^{\circ}$, a camera optimization procedure is run in order to compute the intrinsic camera calibration parameters for each survey and to further precisely georeference the sparse 3D point cloud using the GCP coordinates; (3) a dense 3D colored point cloud is generated (41 million and 93 million points for DP2 and DP4P, respectively); (4) structured textured DSMs are built with MATLAB from the dense 3D point cloud using natural neighbor interpolation in order to compute the beach-dune system morphological evolution on a $0.1 \times 0.1 \mathrm{~m}$ structured grid. It is noteworthy that although Photoscan is used here, similar overall performances can be obtained with other stereo-photogrammetry commercial or free software [43].

\subsection{Validation Experiment Set-Up}

The accuracy of the survey methods was addressed during a devoted experiment performed on 13 March 2018 at Truc Vert Beach, during which the weather was cloudy with low wind conditions (average of $2.0 \mathrm{~m} / \mathrm{s}$ ). The flight characteristics for the two UAVs were the same as those described in Section 3.1. However, a smaller area of $350 \mathrm{~m} \times 1000 \mathrm{~m}$ was chosen in order to address the resolution and accuracy of the surveys, meaning that only 10 out of 36 GCPs were used (P1-10 in Figure 3). On the day of the validation experiment, 65 validation points composed of 5 transects of 13 points covering the entire system from the beach to the grey dune were measured using a DGPS with centimetric horizontal and vertical accuracy. The measured elevation of the validation points is compared with the DSM grid cell elevation at the corresponding position. The mean distance between the validation points and the grid cell centers was $0.037 \mathrm{~m}$ with a minimum and maximum distance of $0.008 \mathrm{~m}$ and $0.064 \mathrm{~m}$, respectively. In order to estimate the accuracy of the DSMs, two statistical parameters were used, namely elevation root-mean-square (RMS) error (Equation (1)) and bias (Equation (2)):

$$
\begin{gathered}
\text { RMS_Z }=\sqrt{\frac{\sum_{n}\left(z_{\mathrm{DGPS}}-z_{\mathrm{DSM}}\right)^{2}}{n},} \\
\text { Bias_Z }=\frac{\sum_{n}\left(z_{\mathrm{DGPS}}-z_{\mathrm{DSM}}\right)}{n},
\end{gathered}
$$

where $z_{\mathrm{DGPS}}$ and $z_{\mathrm{DSM}}$ are the elevations measured with the DGPS and obtained from the DSM, respectively, and $n$ is the number of validation points. 


\section{Results}

\subsection{Validation Experiment Results}

Figure 4 shows the relative elevation error between the DSM and the DGPS ground survey points over the 3D textured DSM for DP2 (Figure 4a) and DP4P (Figure 4b). For DP2, the RMS_Z error is $0.13 \mathrm{~m}$ and Bias_Z is $-0.1 \mathrm{~m}$. The calculated elevations are slightly underestimated, particularly across the beach and the incipient foredune $(0.2-0.3 \mathrm{~m})$. The underestimation is lower in the foredune and in the grey dune with values between $0 \mathrm{~m}$ and $0.05 \mathrm{~m}$ (Figure 4a). DP4P shows an overall RMS_Z error of $0.05 \mathrm{~m}$ and a Bias_Z of $-0.02 \mathrm{~m}$. The underestimation of the beach and the incipient foredune elevation is between $0 \mathrm{~m}$ and $0.1 \mathrm{~m}$. Only two points, located on the beach and on the foredune, show a relative elevation error exceeding $0.1 \mathrm{~m}$ with an underestimation of $0.17 \mathrm{~m}$ and an overestimation of $0.13 \mathrm{~m}$ respectively (Figure $4 \mathrm{~b}$ ). Of note, the mean errors found here are similar magnitude as in reference [41] using optimal edge or stratified GCP spatial distribution.

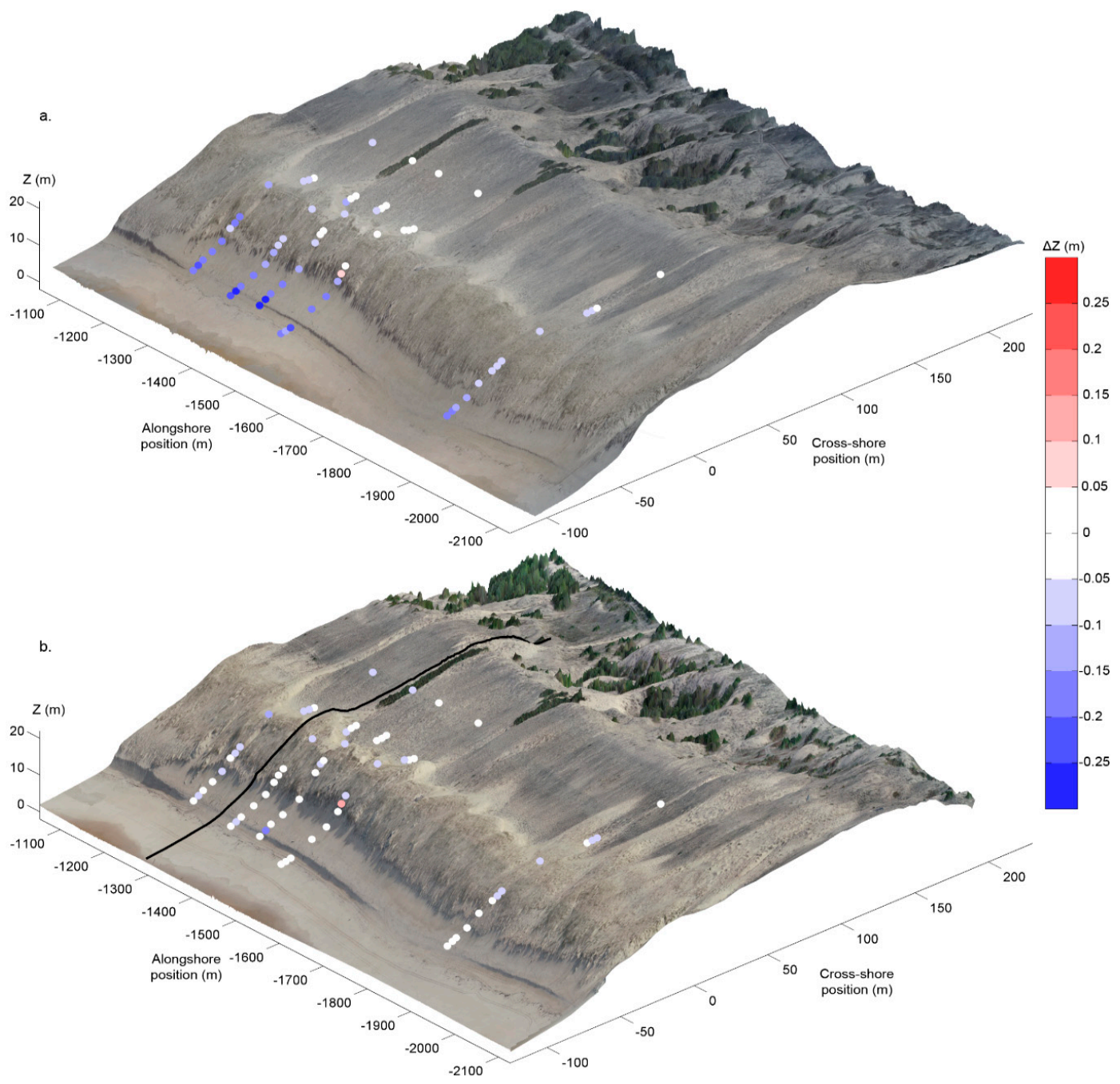

Figure 4. Elevation relative error (colored circles) between the DSM, generated using 10 GCPs, and the DGPS ground survey superimposed onto the 3D textured DSM for (a) DP2 and (b) DP4P. The DSM in $(\mathbf{a}, \mathbf{b})$ were generated with DP2 and DP4P images, respectively. The black line shows the cross-shore profile presented in Figure 5.

GCPs P1-P10 have been used in order to address the influence of the GCP spatial distribution and density on the overall DSM accuracy. The 3D point clouds generated with DP2 and DP4P were calibrated using 3 to 10 GCPs distributed uniformly, removing GCPs in the following order: P8, P3, 
P7, P4, P5, P6 and P10 (see Figure 3). Table 1 shows the error at the validation points for both UAVs as a function of the number of GCPs used to infer the DSM. Using 3 or 4 GCPs shows large errors of several tens of centimeters. However, the DP2 DSM has a RMS_Z error and a Bias_Z twice as low as that of the DP4P DSM. Using from 5 to 10 GCPs, the RMS_Z error and the Bias_Z show similar skill, $0.14 \mathrm{~m}$ and $-0.11 \mathrm{~m}$ on average for DP2 and $0.05 \mathrm{~m}$ and $-0.03 \mathrm{~m}$ on average for DP4P, respectively. The planimetric error cannot be calculated at the validation points and was calculated at the GCPs, together with the altimetric error. Rationally, it gives better results than for the validation points but allows for a comparison between altimetric and planimetric errors. The planimetric RMS error for the model using 10 GCPs is $0.04 \mathrm{~m}$ with DP4P and $0.07 \mathrm{~m}$ with DP2. These errors are larger than the altimetric errors $(0.01 \mathrm{~m}$ with DP4P and 0.03 with DP2) but still remain on the order of a few centimeters, which largely meet the accuracy requirements to monitor dune morphological changes at the scale of a single severe windstorm.

Table 1. DSM RMS_Z error and Bias_Z calculated at the validation points for DP2 and DP4P using different numbers of GCPs.

\begin{tabular}{clccc}
\hline Number of GCP & \multicolumn{2}{c}{ RMS_Z Error $(\mathbf{m})$} & \multicolumn{2}{c}{ Bias_Z $\mathbf{( m )}$} \\
\hline & DP2 & DP4P & DP2 & DP4P \\
3 & 0.67 & 1.44 & -0.65 & -1.41 \\
4 & 0.50 & 1.12 & -0.49 & -1.10 \\
5 & 0.14 & 0.05 & -0.11 & -0.03 \\
6 & 0.14 & 0.05 & -0.10 & -0.03 \\
7 & 0.14 & 0.05 & -0.09 & -0.03 \\
8 & 0.15 & 0.05 & -0.11 & -0.02 \\
9 & 0.15 & 0.05 & -0.11 & -0.02 \\
10 & 0.13 & 0.05 & -0.10 & -0.02 \\
\hline
\end{tabular}

\subsection{Large Scale Application to a Rapidly Evolving Coastal Dune}

Figure 5 shows the characteristics of a typical cross-shore beach-dune profile (black profile in Figure $4 b$ ). The incipient foredune morphology is complex as a result of the winter of 2013/2014 that caused large beach and dune erosion at Truc Vert [29]. During that period the incipient foredune locally retreated by $10-20 \mathrm{~m}$, and was locally entirely eroded in the center of the megacusp embayments. Since then, a second incipient foredune developed seaward of the incipient foredune erosion scarp [32]. In March 2018, the top of this former erosion scarp was still observed along most of the study site (Figure 5).

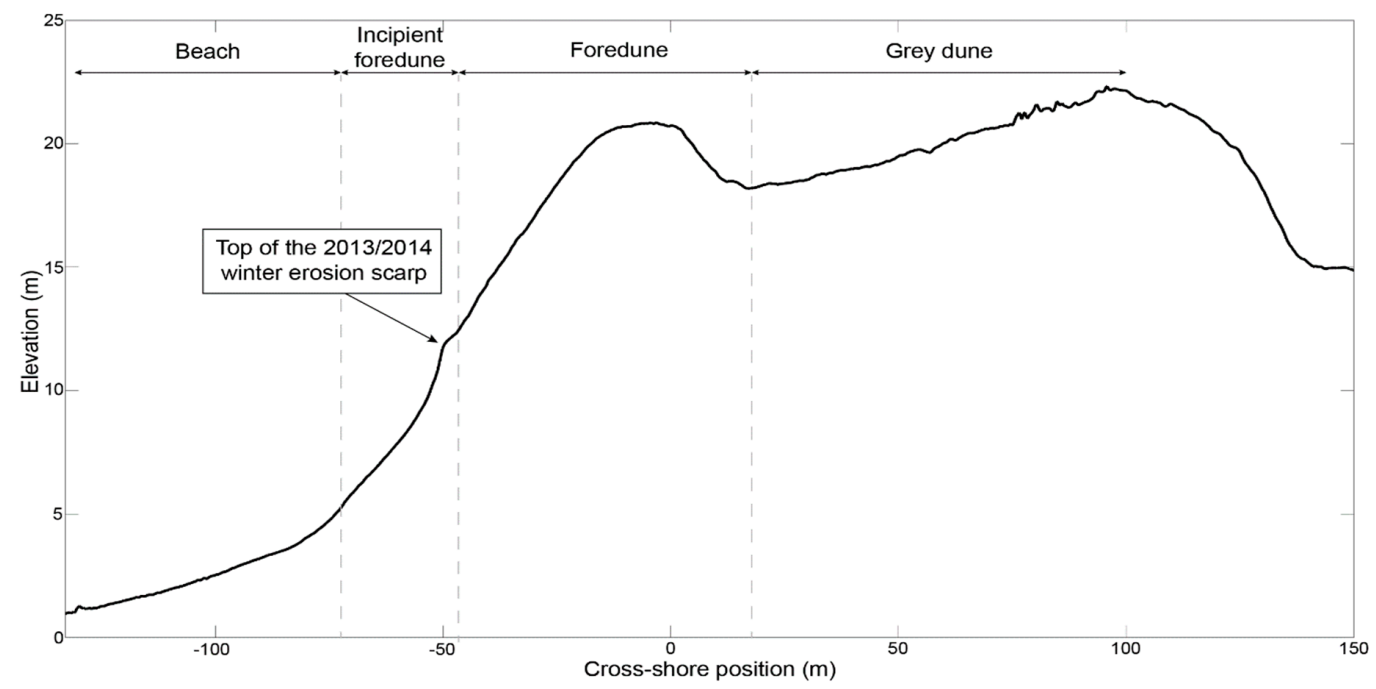

Figure 5. Cross-shore profile of the beach-dune system at Truc Vert showing the different morphological compartments with indication of the location of the 2013/2014 erosion scarp mark. 
Below, the morphological evolution of the beach-dune system is addressed over a 6-month period encompassing the winter of 2017/2018, from 9 October to 13 March, based on 4 photogrammetry-derived DSMs. To achieve this purpose, 36 permanent GCPs implemented in 250-m spaced pairs along the entire 4-km dune system were used (Figure 6). The GCPs density is well larger than the 5 GCPs needed per kilometer according to the validation experiment described above. It ensures accurate DSM along the entire 4-km beach-dune system even in case of the loss of a limited number of GCPs (silting, vandalism, etc.). Figure 6 shows the 4 orthophotos, obtained with DP2 (Figure 6a-c) and DP4P (Figure 6d), highlighting the reasonable alongshore uniformity of the site.

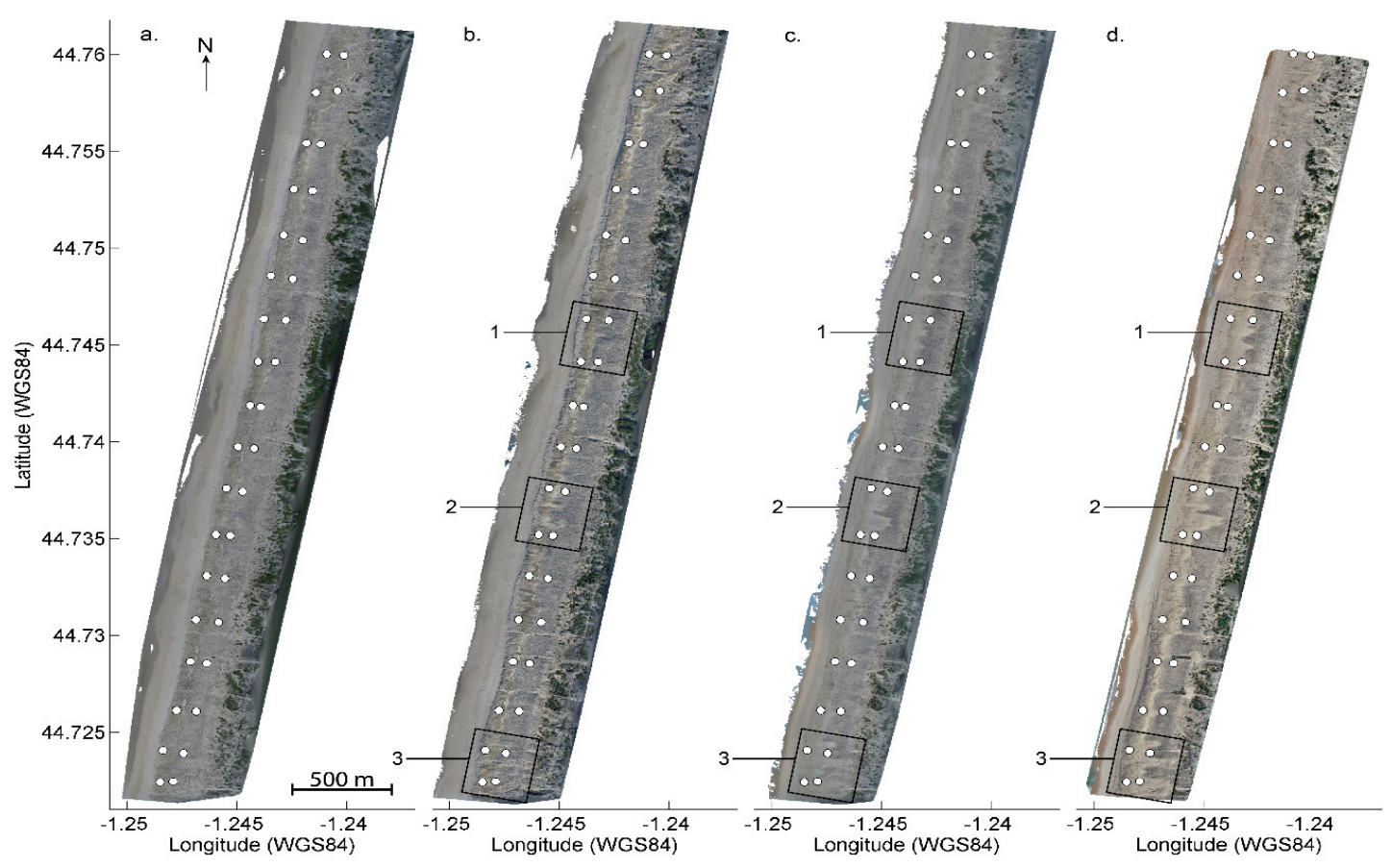

Figure 6. Orthophotos of the entire 4-km study area of Truc Vert beach on (a) 9 October 2017, (b) 19 December 2017, (c) 23 January 2018 and (d) 13 March 2018. The positions of the 36 permanent GCPs implemented in 250-m spaced pairs along the entire 4-km dune system used for the DSM generation are indicated by white dots and the black squares show the areas zoomed onto in Figure 7.

Figure 7 zooms onto the 3 zones shown in Figure 6. Overall, the high-energy waves during the $2017 / 2018$ winter drove large beach erosion, with the beach lowering by $1.5 \mathrm{~m}$ on average and locally reaching $2.5 \mathrm{~m}$. The incipient foredune shows a vertical accretion of $0.3 \mathrm{~m}$ on average, peaking locally at $0.6 \mathrm{~m}$. In the meantime, the incipient foredune locally retreated by up to $10 \mathrm{~m}$ forming an erosion scarp up to 2-m high. In addition, the top of the 2013/2014 scarp further eroded by $0.5 \mathrm{~m}$ on average. The foredune shows a reasonably alongshore-uniform vertical accretion of $0.4 \mathrm{~m}$ on average which is maximized $(\sim 1.1 \mathrm{~m})$ at the crest and at the lee side of the foredune. Moreover, results show an overall landward migration of the foredune as well as substantial sand deposition on the grey dune. These strongly alongshore-variable deposition patterns have a typical thicknesses of $0.1-0.3$ m extending landward approximately $25 \mathrm{~m}, 40 \mathrm{~m}$ and $35 \mathrm{~m}$ for the northern, central and southern zones, respectively (right-hand panels in Figure 8). These deposition patterns are readily present on the orthophotos where the grey dune vegetation is buried (Figure $7 \mathrm{a}, \mathrm{c}, \mathrm{e}, \mathrm{h}, \mathrm{j}, 1, \mathrm{o}, \mathrm{q}, \mathrm{s}$ ).

These overall morphological changes show substantial temporal variability. During the first period between 9 October 2017 and 19 December 2017 (left-hand panels in Figure 7) small morphological changes were observed. Substantial beach accretion occurred (vertical accretion of $0.2 \mathrm{~m}$ on average), except locally (Figure $7 \mathrm{~b}$ ) while the incipient foredune lowered by $0.2 \mathrm{~m}$ on average in the central (Figure 7i) and southern zones (Figure 7p). During that period, only the foredune in the northern 
zone shows some vertical accretion of approximately $0.2 \mathrm{~m}$ (Figure $7 \mathrm{~b}$ ). The largest morphological changes are observed during the second period from 19 December 2017 and 23 January 2018, which was characterized by a succession of storm wind and wave events. The beach lowered by up to $0.8 \mathrm{~m}$, with the incipient foredune (foredune) accreting vertically by $0.5 \mathrm{~m}(0.4 \mathrm{~m})$ on average peaking at $0.7 \mathrm{~m}$ $(0.8 \mathrm{~m})$ (Figure $7 \mathrm{~d}, \mathrm{k}, \mathrm{r})$. The third period from 23 January 2018 to 13 March 2018 shows that, although the beach further lowered by $0.6 \mathrm{~m}$ on average, only small morphological changes were observed on the dune although changes occurred on larger spatial scales (Figure $7 \mathrm{~g}, \mathrm{n}, \mathrm{u}$ ). The formation of three breaches, two in the northern zone and one in the central zone (Figure $7 \mathrm{~b}, \mathrm{i}$ ), between 9 October 2017 and 19 December 2017 is not linked to the action of natural processes but to the experimental set up of transverse blowouts dug on 12 December 2017 for another study [46].
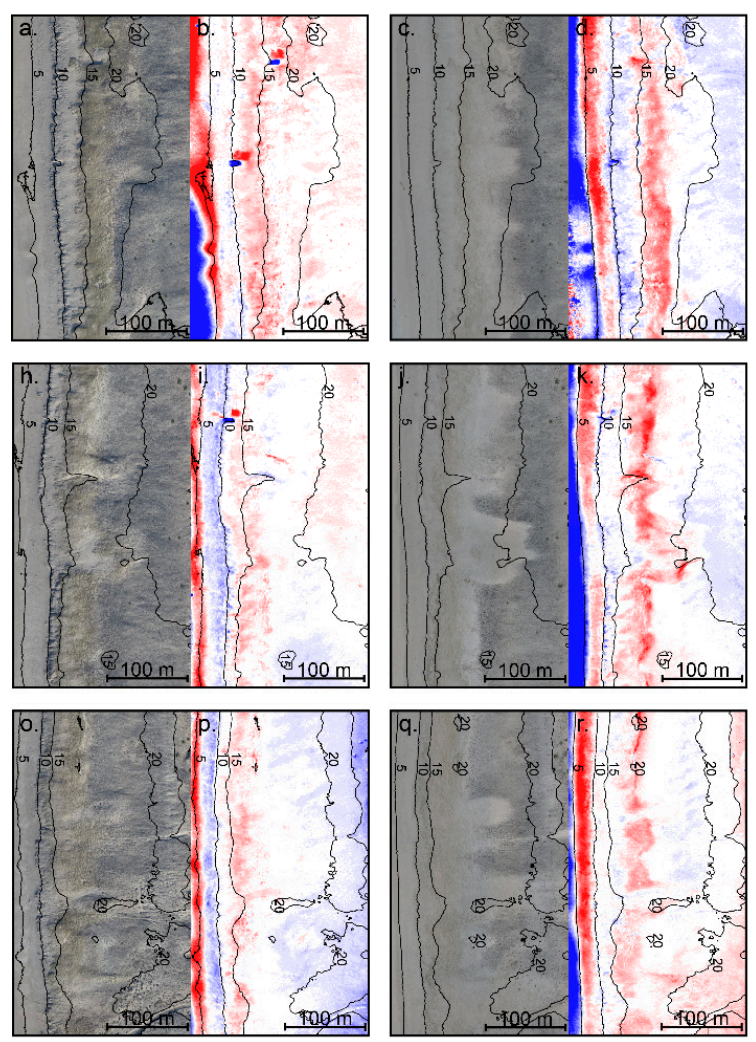
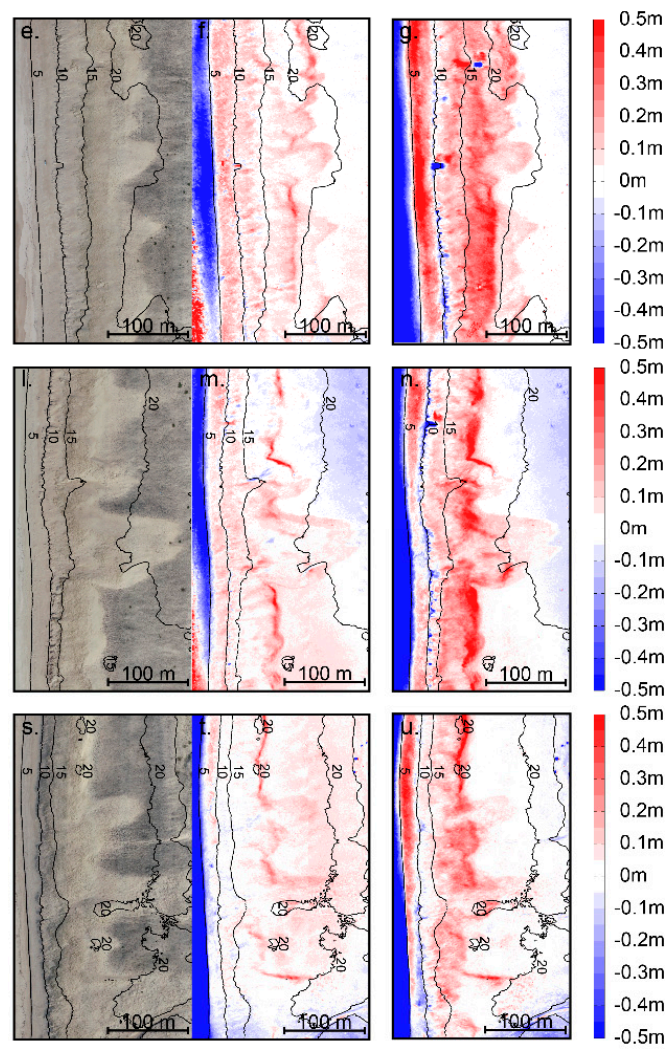

Figure 7. Beach-dune morphological changes zoomed onto the areas shown by the black squares in Figure 6. (a-g) northern area; $(\mathbf{h}-\mathbf{n})$ central area; $(\mathbf{o}-\mathbf{u})$ southern area. Orthophotos of Truc Vert beach generated with DP2 on (a,h,o) 19 December 2017, (c,j,, $\mathbf{q}) 23$ January 2018, and generated with DP4P on $(\mathbf{e}, \mathbf{l}, \mathbf{s}) 13$ March 2018, are shown with the corresponding DSM difference plot between 9 October 2017 and 19 December 2017 (b,i,p), 19 December 2019 and 23 January 2018 (d, $\mathbf{k}, \mathbf{r})$ and 23 January 2018 and 13 March $2018(\mathbf{f}, \mathbf{m}, \mathbf{t})$. The right-hand panels $(\mathbf{g}, \mathbf{n}, \mathbf{u})$ shows the DSM difference plot for the entire study period between 9 October 2017 and 13 March 2018. The colorbar indicates the elevation difference in meters.

Figure 8 shows the 4-km alongshore-averaged morphological change of the beach-dune profile between 9 October 2017 and 13 March 2018. The beach lowered by 1-1.5 m on average. The overall morphological changes of the foredune and incipient foredune are more subtle owing to the alongshore averaging. A prominent change is that of the foredune, which accreted vertically by up to $0.35 \mathrm{~m}$ on average along a cross-shore distance of approximately $100 \mathrm{~m}$ (Figure 8b). 

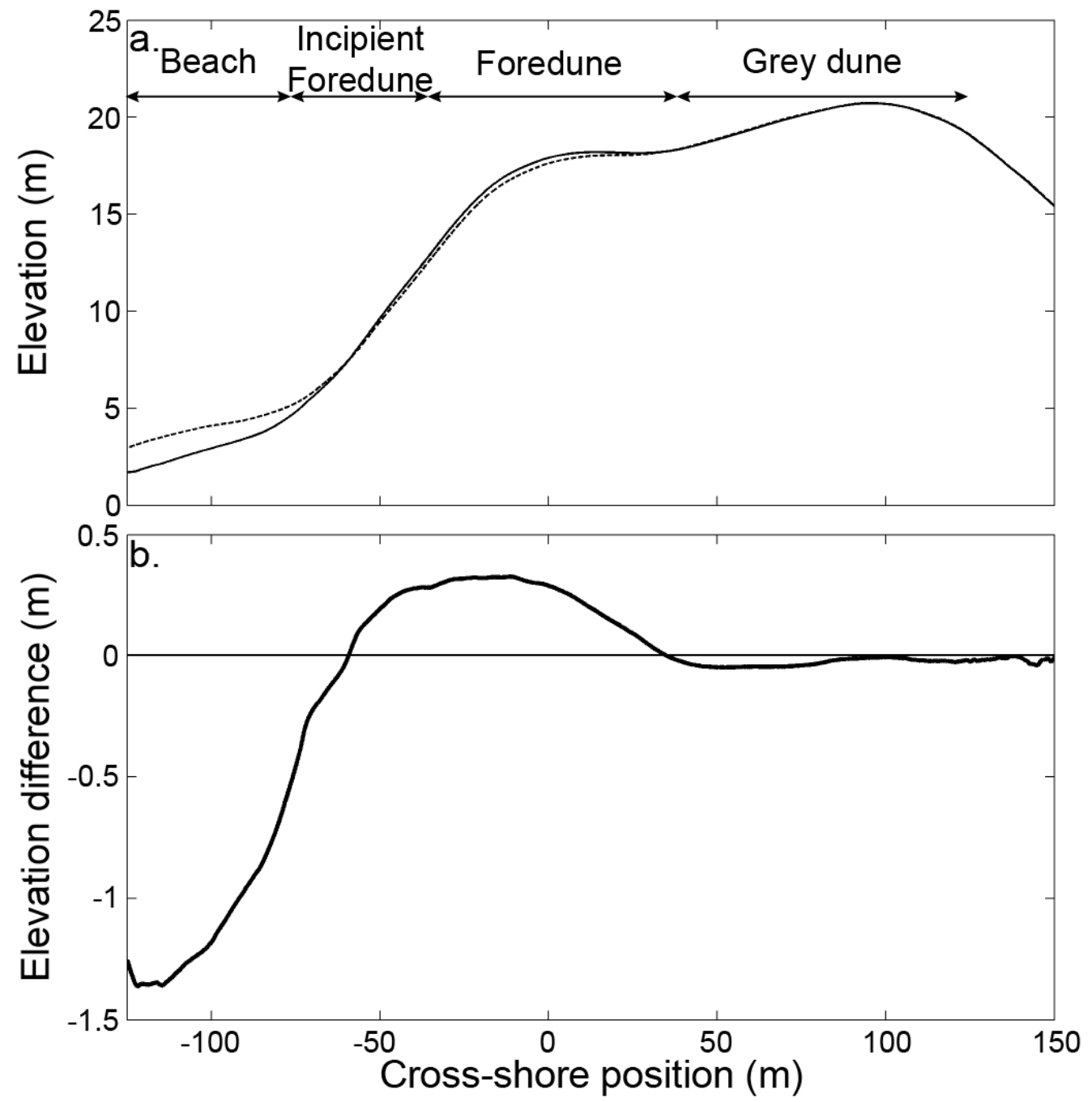

Figure 8. (a) 4-km alongshore-averaged beach-dune profile at Truc Vert on 9 October 2017 obtained with DP2 (dotted black line) and on 13 March 2018 obtained with DP4P (black line) with (b) corresponding elevation change between 9 October 2017 (survey performed with DP2) and 13 March 2018 (survey performed with DP4P).

\section{Discussion}

Although the DSM retrieved from DP2 shows high accuracy across the dune system, locally strong elevation underestimation was observed on the dry beach. This was primarily caused by the locally smooth and featureless sand surface providing poor structure for the detection of remarkable points needed for SfM algorithm. Results slightly worsen on the established foredune. The established foredune is densely vegetated with marram grass up to $0.5-\mathrm{m}$ high (Figure $2 \mathrm{~b}$ ) that is detected by the SfM algorithm, while the sand level was surveyed with the DGPS, which can explain the difference.

The RMS_Z error and Bias_Z are affected by the number of GCPs used. The large errors of the 3D dense point clouds using 3 or 4 GCPs for the small $350 \mathrm{~m} \times 1000 \mathrm{~m}$ area of the validation experiment are due to a twist of the DSM, the GCPs being quasi-aligned. This DSM twist issue is a common problem when the study area is large in one preferred direction. This twist can be explained by the 3D point cloud generation method, which requires at least three GCPs to create the space in which the points are located. Two to three additional GCPs must be added within this $350 \mathrm{~m} \times 1000 \mathrm{~m}$ area in order to resolve the camera's intrinsic parameters and thus increase DSM accuracy. Surprisingly, when using less than 5 GCPs on the same area, the DSM computed using DP2 shows an RMS_Z error twice as weak as that computed using DP4P. 
The use of 5 CGPs for the $350 \mathrm{~m} \times 1000 \mathrm{~m}$ domain is the minimum requirement in order to reach satisfactory accuracy with a RMS_Z error and Bias_Z for DP4P of approximately $0.05 \mathrm{~m}$ and $-0.03 \mathrm{~m}$, respectively. RMS_Z error and Bias_Z are 3 and 5 times higher with DP2, respectively. Results further show that increasing the number of GCPs from 5 up to 10 only slightly increases DSM accuracy, meaning that (1) implementing 2 cross-shore GCPs every $250 \mathrm{~m}$ alongshore is enough to derive accurate DSMs and (2) including GCPs on the beach is not a necessary requirement. The spatial distribution strategy of 250-m spaced pairs of GCPs ensures that the potential loss of a small number of GCPs due to human degradation or rapid sand silting will not significantly degrade the inferred DSMs. These results also show that DP4P, together with permanent GCPs, is a very good choice to perform low-cost but accurate dune surveys, leading to DSM vertical precision similar to what can be obtained with much more expensive real time cinematic drones $(\sim 0.05 \mathrm{~cm}$ according to technical specifications). However, the resolution and accuracy obtained with DP2 largely meets the requirements for beach-dune monitoring.

Using 36 permanent GCPs to monitor $4 \mathrm{~km}$ of beach-dune system DSM elevation differences from 9 October 2017 to 13 March 2018 show substantial morphological changes from the beach to the coastal dune. The largest morphological changes were observed between 19 December 2017 and 23 January 2018. During this period, three major storm events hit the coast, in particular between 26 December 2017 and 3 January 2018, when wind gusts velocity exceeded $33 \mathrm{~m} / \mathrm{s}$ and significant wave heights reached $8 \mathrm{~m}$ offshore. These highly energetic conditions drove widespread beach erosion with the formation of localized erosion scarps on the upper beach, and locally against the incipient foredune. This large alongshore variability in beach and dune response highlights the need to encompass kilometers of coast. In addition, small morphological features, such as local dune scarps and blowouts, to large sand patches, and even kilometer-scale alongshore erosion features, such as megacusp embayments, are well captured. Given that all these morphological patterns are of primary concern for coastal dune stakeholders, such monitoring can have strong implications from the perspective of coastal management.

Compared to the methods described previously (i.e., terrestrial and airborne LiDAR), one of the major problems with UAV surveys is the weather, in particular the wind velocity that must be lower than $7 \mathrm{~m} / \mathrm{s}$ to use small (less than $2 \mathrm{~kg}$ ) multirotor UAVs [47]. Nonetheless, UAVs offer many advantages such as low cost; survey automation; high repeatability; direct video return; the ability to easily pause and resume a mission if facing unexpected problem; little preparation allowing a high reactivity after extreme events, and high-resolution accurate DSMs over a few kilometers. For larger areas (say O (10-100 km)) airborne or satellite solutions should be preferred.

\section{Conclusions}

In this paper, a low-cost and lightweight UAV-camera photogrammetry method combined with simple and efficient permanent GCP set-up was proposed and further used to accurately (RMS_Z error $<0.1 \mathrm{~m})$ monitor the morphological changes of the beach-dune system at high-resolution $(<0.1 \mathrm{~m})$ on large spatial scales ( $4 \mathrm{~km}$ alongshore). The remotely-sensed DSM of two UAVs (fisheye-camera equipped DP2 and DP4P) were compared for different GCPs implementation strategies. Overall, the DP4P provides slightly better results with a RMS_Z error and a Bias_Z of approximately $0.05 \mathrm{~m}$ and $-0.02 \mathrm{~m}$, respectively, with flight and computation times quite similar for the 2 UAVs. However, the DSM accuracy inferred from the GoPro-equipped DP2P still largely meets the standard for coastal monitoring and coastal dune management objectives. Compared to other methods, terrestrial or airborne LiDAR surveys, the non-intrusive approach presented here is cheaper, more accurate and more flexible to survey beach-dune systems and to further address wind- and wave-driven morphological changes on a wide range of spatial and temporal scales. It is illustrated herein over a 6-month winter period along $4 \mathrm{~km}$ of the beach-dune system at Truc Vert showing, for instance, alongshore variable beach and incipient foredune wave-driven erosion, and the storm-wind driven inland migration by a few meters of the established fordune and 0.1-0.3-m sand deposition on the 
grey dune. This photogrammetry approach via low-cost flexible and lightweight UAVs is well adapted for coastal research groups and coastal dune stakeholders monitoring and managing the coastal zone, including in developing countries where data are lacking and when the weather conditions are suitable.

Author Contributions: Conceptualization, Q.L.-F., V.M. and B.C.; Formal analysis, Q.L.-F.; Funding acquisition, B.C.; Investigation, Q.L.-F., V.M. and B.C.; Methodology, Q.L.-F., V.M., B.C., R.M., S.B. and D.R.; Validation, Q.L.-F.; Writing-original draft, Q.L.-F.; Writing—review \& editing, V.M. and B.C.

Funding: This research was funded by Agence National de la Recherche (ANR) grant ANR-14-ASTR-0004 (CHIPO project) and ANR-17-CE01-0014 (SONO project). Additional funding was provided by Service National d'Observation (SNO) Dynalit labelled by CNRS-INSU, program AST “Evènements extrêmes" of the Observatoire Aquitain des Sciences de l'Univers (OASU) and Observatoire de la Côte Aquitaine (OCA).

Acknowledgments: Truc Vert is a monitoring site of SNO Dynalit labelled by CNRS-INSU. Storage resources for this study was provided by the computing facilities MCIA (Mésocentre de Calcul Intensif Aquitain) of Univ. Bordeaux and Univ. Pau et Pays de l'Adour. We thank the two anonymous reviewers for their constructive comments that improved the quality of the paper.

Conflicts of Interest: The authors declare no conflict of interest.

\section{References}

1. Marzolff, I.; Poesen, J. The potential of 3D gully monitoring with GIS using high-resolution aerial photography and a digital photogrammetry system. Geomorphology 2009, 111, 48-60. [CrossRef]

2. Mancini, F.; Dubbini, M.; Gattelli, M.; Stecchi, F.; Fabbri, S.; Gabbianelli, G. Using unmanned aerial vehicles (UAV) for high-resolution reconstruction of topography: The structure from motion approach on coastal environments. Remote Sens. 2013, 5, 6880-6898. [CrossRef]

3. Gonçalves, J.A.; Henriques, R. UAV photogrammetry for topographic monitoring of coastal areas. ISPRS J. Photogramm. Remote Sens. 2015, 104, 101-111. [CrossRef]

4. Brunier, G.; Fleury, J.; Anthony, E.J.; Gardel, A.; Dussouillez, P. Close-range airborne Structure-from-Motion Photogrammetry for high-resolution beach morphometric surveys: Examples from an embayed rotating beach. Geomorphology 2016, 261, 76-88. [CrossRef]

5. Turner, I.L.; Harley, M.D.; Drummond, C.D. UAVs for coastal surveying. Coast. Eng. 2016, 114, $19-24$. [CrossRef]

6. Guisado-Pintado, E.; Jackson, D.W.T.; Rogers, D. 3D mapping efficacy of a drone and terrestrial laser scanner over a temperate beach-dune zone. Geomorphology 2019, 328, 157-172. [CrossRef]

7. Long, N.; Millescamps, B.; Guillot, B.; Pouget, F.; Bertin, X. Monitoring the topography of a dynamic tidal inlet using UAV imagery. Remote Sens. 2016, 8, 387. [CrossRef]

8. Mancini, F.; Castagnetti, C.; Rossi, P.; Dubbini, M.; Fazio, N.L.; Perrotti, M.; Lollino, P. An Integrated Procedure to Assess the Stability of Coastal Rocky Cliffs: From UAV Close-Range Photogrammetry to Geomechanical Finite Element Modeling. Remote Sens. 2017, 9, 1235. [CrossRef]

9. Rüdiger, J.; Tirpitz, J.-L.; de Moor, J.M.; Bobrowski, N.; Gutmann, A.; Liuzzo, M.; Ibarra, M.; Hoffmann, T. Implementation of electrochemical, optical and denuder-based sensors and sampling techniques on UAV for volcanic gas measurements: Examples from Masaya, Turrialba and Stromboli volcanoes. Atmos. Meas. Tech. 2018, 11, 2441-2457. [CrossRef]

10. Smith, M.W.; Vericat, D. From experimental plots to experimental landscapes: Topography, erosion and deposition in sub-humid badlands from Structure-from-Motion photogrammetry. Earth Surf. Process. Landf. 2015, 40, 1656-1671. [CrossRef]

11. Westoby, M.J.; Brasington, J.; Glasser, N.F.; Hambrey, M.J.; Reynolds, J.M. 'Structure- from-motion' photogrammetry a low-cost, effective tool for geoscience applications. Geomorphology 2012, 179, 300-314. [CrossRef]

12. Stive, M.J.F.; Aarninkhof, S.G.J.; Hamm, L.; Hanson, H.; Larson, M.; Wijnberg, K.M.; Nicholls, R.J.; Capobianco, M. Variability of shore and shoreline evolution. Coast. Eng. 2002, 47, 211-235. [CrossRef]

13. Perko, R.; Raggam, H.; Gutjahr, K.; Schardt, M. Assessment of the mapping potential of Pleiades stereo and triplet data. In Proceedings of the ISPRS Conference on ISPRS Annals of the Photogrammetry, Remote Sensing and Spatial Information Sciences, Zurich, Switzerland, 5-7 September 2014; Volume II-3, pp. $103-109$. 
14. Donker, J.; Van Maarseveenand, M.; Ruessink, G. Spatio-temporal variations in foredune dynamics determined with Mobile Laser Scanning. J. Mar. Sci. Eng. 2018, 6, 126. [CrossRef]

15. Le Mauff, B.; Juigner, M.; Ba, A.; Marc, R.; Launeau, P.; Fattal, P. Coastal monitoring solutions of the geomorphological response of beach-dune systems using multi-temporal LiDAR datasets (Vendée coast, France). Geomorphology 2018, 304, 121-140. [CrossRef]

16. Ruessink, B.; Arens, S.; Kuipers, M.; Donker, J. Coastal dune dynamics in response to excavated foredune notches. Aeolian Res. 2018, 31, 3-17. [CrossRef]

17. Eisemann, E.R.; Wallace, D.J.; Buijsman, M.C.; Pierce, T. Response of a vulnerable barrier island to multi-year storm impacts: LiDAR-data-inferred morphodynamic changes on Ship Island, Mississippi, USA. Geomorphology 2018, 313, 58-71. [CrossRef]

18. Letortu, P.; Jaud, M.; Grandjean, P.; Ammann, J.; Costa, S.; Maquaire, O.; Davidson, R.; Le Dantec, N.; Delacourt, C. Examining high-resolution survey methods for monitoring cliff erosion at an operational scale. GISci. Remote Sens. 2018, 55, 457-476. [CrossRef]

19. Fabbri, S.; Giambastiani, B.M.S.; Sistilli, F.; Scarelli, F.; Gabbianelli, G. Geomorphological analysis and classification of foredune ridges based on Terrestrial Laser Scanning (TLS) technology. Geomorphology 2017, 295, 436-451. [CrossRef]

20. Delacourt, C.; Allemand, P.; Jaud, M.; Grandjean, P.; Deschamps, A.; Ammann, J.; Cuq, V.; Suanez, S. DRELIO: An Unmanned Helicopter for Imaging Coastal Areas. J. Coast. Res. 2009, 56, 1489-1493.

21. Bryson, M.; Johnson-Roberson, M.; Murphy, R.; Bongiorno, D. Kite Aerial Photography for Low-Cost, Ultra-high Spatial Resolution Multi-Spectral Mapping of Intertidal Landscapes. PLoS ONE 2013, 8, e73550. [CrossRef] [PubMed]

22. Jaud, M.; Grasso, F.; Le Dantec, N.; Verney, R.; Delacourt, C.; Ammann, J.; Deloffre, J.; Grandjean, P. Potential of UAVs for Monitoring Mudflat Morphodynamics (Application to the Seine Estuary, France). ISPRS Int. J. Geo-Inf. 2016, 5, 50. [CrossRef]

23. Hesp, P.A.; Walker, I.J. Aeolian environments: Coastal dunes. In Treatrise on Geomorphology, Volume 11: Aeolian Geomorphology; Shroder, J., Lancaster, N., Sherman, D.J., Baas, A.C.W., Eds.; Academic Press: San Diego, CA, USA, 2013; pp. 109-133.

24. Houser, C.; Wernette, P.; Rentschlar, E.; Jones, H.; Hammond, B.; Trimble, S. Post-storm beach and dune recovery: Implications for barrier island resilience. Geomorphology 2015, 234, 54-63. [CrossRef]

25. Psuty, N.P.; Silveira, T.M. Global climate change: An opportunity for coastal dunes? J. Coast. Conserv. 2010, 14, 153-160. [CrossRef]

26. Seabloom, E.W.; Ruggiero, P.; Hacker, S.D.; Mull, J.; Zarnetske, P. Invasive grasses, climate change, and exposure to storm-wave overtopping in coastal dune ecosystems. Glob. Chang. Biol. 2013, 19, 824-832. [CrossRef] [PubMed]

27. Martinez, M.L.; Hesp, P.A.; Gallego-Fernandez, J.B. Coastal dunes: Human impact and need for restoration. In Restoration of Coastal Dunes; Martinez, M.L., Gallego-Fernández, J.B., Hesp, P., Eds.; Springer: Berlin/Heidelberg, Germany, 2013; pp. 1-14.

28. Nordstrom, K.F. Beaches and Dunes of Developed Coasts; Cambridge University Press: Cambrige, UK, 2000.

29. Castelle, B.; Marieu, V.; Bujan, S.; Splinter, K.D.; Robinet, A.; Sénéchal, N.; Ferreira, S. Impact of the winter 2013-2014 series of severe Western Europe storms on a double-barred sandy coast: Beach and dune erosion and megacusp embayments. Geomorphology 2015, 238, 135-148. [CrossRef]

30. Guisado-Pintado, E.; Jackson, D.W.T. Multi-scale variability of storm Ophelia 2017: The importance of synchronised environmental variables in coastal impact. Sci. Total Environ. 2018, 630, 287-301. [CrossRef] [PubMed]

31. Thornton, E.B.; MacMahan, J.H.; Sallenger, A.H., Jr. Rip currents, mega-cusps, and eroding dunes. Mar. Geol. 2007, 240, 151-167. [CrossRef]

32. Castelle, B.; Bujan, S.; Ferreira, S.; Dodet, G. Foredune morphological changes and beach recovery from the extreme 2013/2014 winter at a high-energy sandy coast. Mar. Geol. 2017, 385, 41-55. [CrossRef]

33. Castelle, B.; Guillot, B.; Marieu, V.; Chaumillon, E.; Hanquiez, V.; Bujan, S.; Poppeschi, C. Spatial and temporal patterns of shoreline change of a 280-km long high-energy disrupted sandy coast from 1950 to 2014: SWFrance. Estuar. Coast. Shelf Sci. 2018, 200, 212-223. [CrossRef] 
34. Castelle, B.; Dodet, G.; Masselink, G.; Scott, T. A new climate index controlling winter wave activity along the Atlantic coast of Europe: The West Europe Pressure Anomaly. Geophys. Res. Lett. 2017, 44, 1384-1392. [CrossRef]

35. Castelle, B.; Dodet, G.; Masselink, G.; Scott, T. Increased winter-mean wave height, variability, and periodicity in the northeast Atlantic over 1949-2017. Geophys. Res. Lett. 2018, 45, 3586-3596. [CrossRef]

36. Masselink, G.; Castelle, B.; Scott, T.; Dodet, G.; Suanez, S.; Jackson, D.; Floc'h, F. Extreme wave activity during 2013/2014 winter and morphological impacts along the Atlantic coast of Europe. Geophys. Res. Lett. 2016, 43, 2135-2143. [CrossRef]

37. Short, A.D.; Jackson, D.W.T. Beach morphodynamics. In Treatrise on Geomorphology, Volume 10, Coastal Geomorphology; Shroder, J., Lancaster, N., Sherman, D.J., Baas, A.C.W., Eds.; Academic Press: San Diego, CA, USA, 2013; pp. 106-129.

38. Hesp, P.A. Foredunes and blowouts: Initiation, geomorphology and dynamics. Geomorphology 2002, 48, 245-268. [CrossRef]

39. Barrère, P. Dynamics and management of the coastal dunes of the Landes, Gascony, France. In Coastal Dunes: Geomorphology, Ecology and Management for Conservation: Proceedings of the 3rd European Dune Congress Galway, Ireland, 17-21 June 1992; Carter, R.E.A., Ed.; A.A. Balkema: Rotterdam, The Netherlands, 1992; pp. $25-32$.

40. Favennec, J. Principes et évolutions de la gestion dunaire. In Les Rendez-vous Techniques de l'ONF $n^{\circ} 17$; Office National des Forêts: Paris, France, 2007; pp. 22-30.

41. Martínez-Carricondo, P.; Agüera-Vega, F.; Carvajal-Ramírez, F.; Mesas-Carrascosa, F.J.; García-Ferrer, A.; Pérez-Porras, F.J. Assessment of UAV-photogrammetric mapping accuracy based on variation of ground control points. Int. J. Appl. Earth Obs. Geoinf. 2018, 72, 1-10. [CrossRef]

42. Dodet, G.; Castelle, B.; Masselink, G.; Scott, T.; Davidson, M.; Floc'h, F.; Jackson, D.; Suanez, S. Beach recovery from extreme storm activity during the 2013-14 winter along the Atlantic coast of Europe. Earth Surf. Process. Landf. 2019, 44, 393-401. [CrossRef]

43. Niederheiser, R.; MokroA, M.; Lange, J.; Petschko, H.; Prasicek, G.; Elberink, S. Deriving 3D point clouds from terrestrial photographs-Comparison of different sensors and software. Int. Arch. Photogramm. Remote Sens. Spat. Inf. Sci. ISPRS Arch. 2016, 41, 685-692. [CrossRef]

44. Fiorillo, F.; Limongiello, M.; Fernández-Palacios, B.J. Testing GoPro for 3D model reconstruction in narrow spaces. Acta IMEKO 2016, 5, 64-70. [CrossRef]

45. Aguilar, F.; Fernandez, I.; Casanova, J.; Ramos, F.; Aguilar, M.; Blanco, J.; Moreno, J. 3D coastal monitoring from very dense UAV-Based photogrammetric point clouds. Lect. Notes Mech. Eng. 2017, 280, 881-888.

46. Laporte-Fauret, Q.; Castelle, B.; Michalet, R.; Marieu, V.; Rosebery, D.; Bujan, S.; Guillot, B. Suivis morphologiques et écologiques du système dunaire en réponse à la mise en place expérimentale de brèches: Truc Vert, Nouvelle-Aquitaine. In Proceedings of Journées Nationales Génie Côtier-Génie Civil, 15th La Rochelle ed.; Paralia CFL; A. Delanoë: Nantes, France, 2018; pp. 235-244. [CrossRef]

47. DJI. Phantom 4 Disclaimer and Safety Guidelines, V1.2; DJI: Shenzhen, China, 2016. 